\title{
Fire and land cover change in the Palouse Prairie-forest ecotone, Washington and Idaho, USA
}

Penelope Morgan ${ }^{1 *} \mathbb{D}$, Emily K. Heyerdahl ${ }^{2}$, Eva K. Strand ${ }^{1}$, Stephen C. Bunting ${ }^{1}$, James P. Riser II', John T. Abatzoglou ${ }^{3}$, Max Nielsen-Pincus ${ }^{4}$ and Mara Johnson ${ }^{1}$

\begin{abstract}
Background: Prairie-forest ecotones are ecologically important for biodiversity and ecological processes. While these ecotones cover small areas, their sharp gradients in land cover promote rich ecological interaction and high conservation value. Our objective was to understand how historical and current fire occurrences and human development influenced the Palouse Prairie-forest ecotone. We used General Land Office survey field notes about the occurrence of bearing trees to locate historical (1870s to 1880s) prairie, pine savanna, and forest at the eastern edge of the bioregion. We combined LANDFIRE Existing Vegetation classes to contrast historical land cover with current land cover. We reconstructed historical fire occurrence (1650 to 1900) from fire-scarred trees. We used fire and lightning records from 1992 to 2015 to interpret the role of people and lightning.
\end{abstract}

Results: Historically, the ecotone was a matrix of prairie with extensive savanna and some forest. More than half of the ecotone area was prairie, which is now dominated by agriculture, with some residential development. The $16 \%$ of the landscape that was pine savanna is now forest or shrubs, agriculture, perennial vegetation under the Conservation Reserve Program, or developed; no savanna now exists. Forests covered $12 \%$ of the ecotone and these are still mostly forest. Fires were historically frequent, occurring on average every 5 to 8 years at most sites. Lightning was not frequent but could likely have been sufficient to ignite fires that could spread readily given the rolling terrain and long fire season.

Conclusions: Fire was far more frequent historically than currently. Conservation, restoration, and other ongoing land-use changes will likely result in more continuous vegetation and hence fuel for fires. Lightning and people may ignite fires that therefore spread readily in the future. Understanding the past and potential future of fire in the Palouse Prairie bioregion may help us live with fire while conserving ecological values here and in similar prairie-forest ecotones.

Keywords: conservation, edge, fire ecology, General Land Office Survey, land use, landscape change, tree rings

\footnotetext{
* Correspondence: pmorgan@uidaho.edu

${ }^{1}$ Department of Forest, Rangeland, and Fire Sciences, University of Idaho, 875

Perimeter Drive, Moscow, Idaho 83844, USA

Full list of author information is available at the end of the article
} 


\section{Resumen}

Antecedentes: Los ecotonos pradera-bosques son ecológicamente importantes para la diversidad y otros procesos ecológicos. Aunque estos ecotonos cubren áreas pequeñas, sus gradientes pronunciados en cobertura del suelo promueven ricas interacciones ecológicas y altos valores de conservación. Nuestro objetivo fue entender como la ocurrencia de fuegos actuales e históricos y el desarrollo humano influenciaron el ecotono bosque-pradera de Palouse. Utilizamos relevamientos de la Oficina General de Tierras sobre la existencia de árboles remanentes para localizar praderas, sabanas de pino, y bosque históricos (desde 1870 hasta 1880) en el borde este de la bio-región. Combinamos clases de Vegetación Existente de LANDFIRE para contrastar coberturas de suelo históricas con actuales. Construimos ocurrencias históricas de fuego (1650 a 1900) de árboles con cicatrices de fuego. Utilizamos datos de fuegos y de rayos desde 1992 hasta 2015 para interpretar el rol de la gente y de los rayos.

Resultados: Históricamente, el ecotono era una matriz de pradera con extensas sabanas y algo de bosque. Más de la mitad del ecotono era pradera, la cual hoy está dominada por la agricultura, con algún desarrollo residencial. El 16\% del paisaje que fue sabana de pino es ahora bosque o matorral, campos agrícolas o vegetación perenne bajo el programa de Conservación de la Reserva, o desarrollado para residencias; actualmente la sabana no existe. Los bosques cubrían el 12\% del ecotono y permanecen aún como bosques. Históricamente, los fuegos fueron frecuentes y ocurrieron en promedio cada 5 a 8 años en la mayoría de los sitios. Los rayos no fueron tan frecuentes, pero probablemente suficientes para iniciar fuegos que se pudieron propagar rápidamente, debido el terreno ondulado y la extensa temporada de fuego.

Conclusiones: El fuego fue mucho más frecuente históricamente que en la actualidad. La conservación, la restauración y otros cambios actuales en el uso de la tierra, resultarán probablemente en una vegetación más continua y por consiguiente más combustible para fuegos. Los rayos y la gente podrían iniciar fuegos que propaguen más rápidamente en el futuro. Entender el pasado y el potencial futuro de incendios en la bio-región de la pradera de Palouse puede ayudarnos a convivir con el fuego, mientras conservamos valores ecológicos aquí y en ecotonos de pradera-bosque similares

\section{Abbreviations}

CRP: Conservation Reserve Program

EVT: $\quad$ Existing Vegetation Type from LANDFIRE

GLO: General Land Office

IDFG: Idaho Fish and Game

The complexities and cumulative effects of ecological change in the Palouse challenge any inquiry into its deep past. Andrew P. Duffin, Plowed Under, 2007

\section{Background}

Prairie-forest ecotones are often high in biological diversity and ecologically important due to their juxtaposition of habitats. Maintaining prairie-savannaforest mosaics is critical to retaining regional biodiversity in the North American Midwest (Ladwig et al. 2018). However, prairie-forest ecotones have been greatly altered by human activity (Samson and Knopf 1994; Bowman et al. 2011; Harvey et al. 2017). Both prairies and adjacent forests have been reduced in extent and health through agriculture, livestock grazing, fire exclusion, and residential development (Samson and Knopf 1994; Pocewicz et al. 2008), which has likely affected primary productivity, hydrology, and many ecosystem services.

Fires were and are ecologically important in prairies on every continent (Bowman et al. 2009) as they reduce tree encroachment and foster biodiversity (Samson and
Knopf 1994; Bond and Keeley 2005; Harvey et al. 2017). Forest fire occurrence is influenced by landscape context at multiple spatial scales, reflecting the degree to which fires spread from adjacent sites (Hessburg et al. 2015; Merschel et al. 2018). Fires were particularly frequent in prairie-forest ecotones (Arno and Gruell 1983; Kitzberger 2012). In North Dakota, USA, fires in ponderosa pine (Pinus ponderosa Lawson \& C. Lawson) forests were more frequent near prairies than far from them (Brown and Sieg 1999). Conver et al. (2018) suggested that prairie-forest ecotones may have been corridors for fire to spread into forests.

The Palouse Prairie in southeastern Washington and west-central Idaho, USA, has been shaped by intensive agriculture and other land uses since the late 1800s (Fig. 1; Black et al. 1998). The Palouse bioregion (Bailey 1995) in southeastern Washington and west-central Idaho includes rolling hills once dominated by Palouse Prairie, pine savanna, and mixed-conifer forests. The prairie was historically dominated by bunchgrasses and forbs with shrubs on some lee slopes and in intermittent wetlands and draws (Weaver 1917; Daubenmire 1942; Tisdale 1961). The pine savanna included open forests of scattered pine with understories of grasses, forbs, and sometimes shrubs (Weaver 1917). The bioregion was bounded on the east by mixed-conifer forests of 


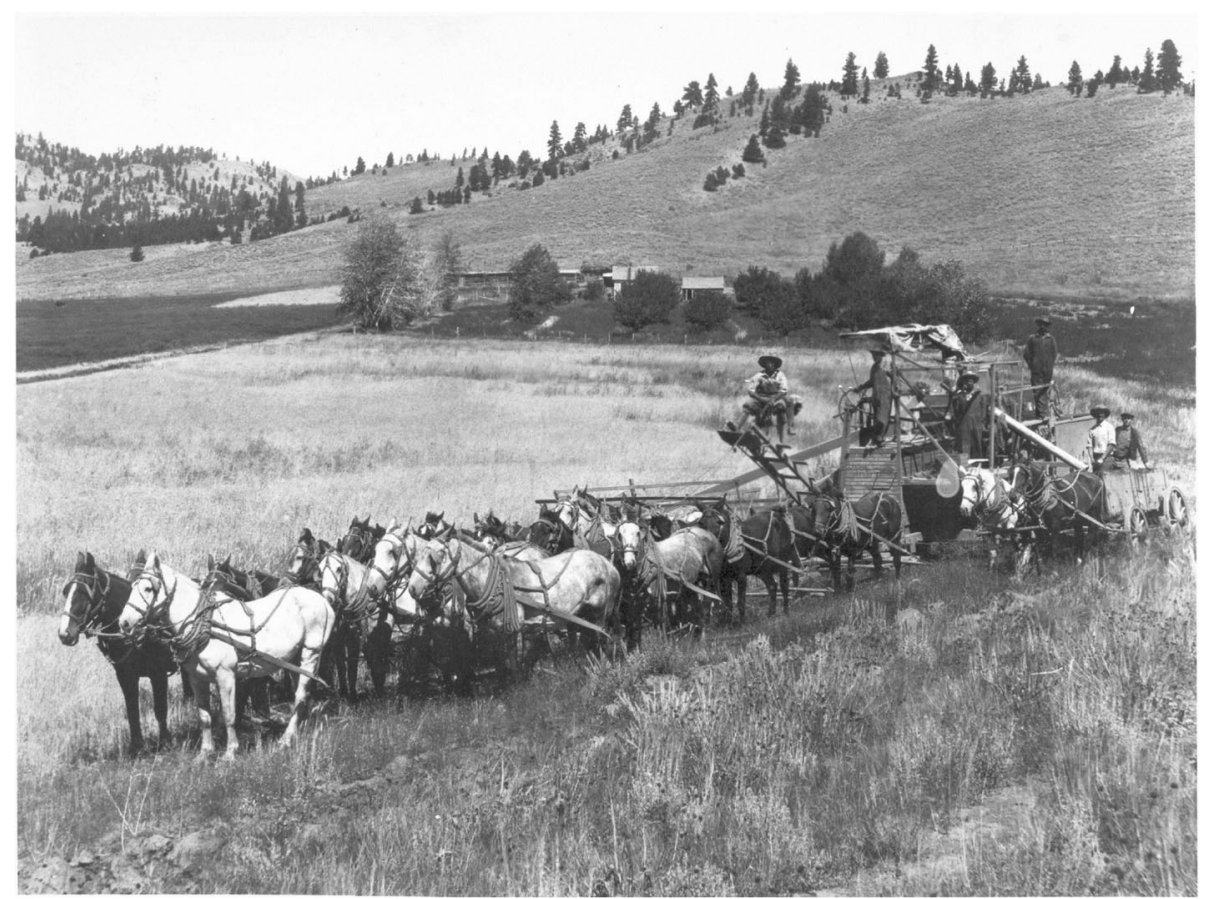

Fig. 1 The Palouse Prairie-forest ecotone in the early 1900s had few fields and houses, as well as native prairie (open hillside), and both pine savanna (slopes and ridges in the background of this photo) and forest (denser with trees than pine savanna). Native Americans cultivated and harvested camas in the intermittent wetlands. Early farmers used large teams of horses to plow the rich prairie soils and harvest the resulting crops; they grazed their horses in the prairie and savanna. Photo credit: Idaho Historical Society, Boise, Idaho, USA

ponderosa pine, Douglas-fir (Pseudotsuga menziesii [Mirb.] Franco), grand fir (Abies grandis [Douglas ex D. Don] Lindl.), western larch (Larix occidentalis Nutt.), and other species (Weaver 1917). Deep, fertile soils make this one of the most productive non-irrigated wheat-growing areas in the world (Donaldson 1980; Barker 1981). Since the early 1900s, most of the land has been privately owned and intensively cultivated, accompanied by towns and residential development (Pocewicz et al. 2008). Noss et al. (1995) declared Palouse Prairie endangered as areal extent was $<1 \%$ of historical extent, and old-growth ponderosa pine forests critically endangered because current (circa 1995) extent is 2 to $15 \%$ of historical extent in the region encompassing the northern Rockies, the Intermountain West, and the eastern Cascades. Furthermore, the mixed-conifer forests that were once dominated by ponderosa pine cover only $54 \%$ of their historical extent, with $37 \%$ of forest and shrublands now dominated by other species such as Douglas-fir and grand fir (Johnson 1999). Ongoing land-use change could further alter this landscape. Regulations, incentives, markets, residential development, and other changes could affect ecological and economic diversity (Pocewicz et al. 2008; Nielsen-Pincus et al. 2010; Goldberg et al. 2011). For example, recent surveys of landowners in the Palouse Prairie (Nielsen-Pincus et al. 2010) and forests in Idaho (Cook et al. 2018) suggest that land cover could change in response to land-use policies and incentives. Current residents along the ecotone between the Palouse Prairie and adjacent forests tend to value aesthetics and recreation more than traditional agriculture (Donovan et al. 2009), which may further hasten conversion of agricultural lands to other land uses, such as residential development, along the ecotone.

Both the Palouse Prairie and open ponderosa pine forests are endangered ecosystems in the USA (Noss et al. 1995). For example, open forests of ponderosa pine are of great conservation importance to Idaho wildlife (IDFG 2015). Conversion of prairie to agriculture has left only small prairie remnants (Tisdale 1961; Black et al. 1998; Looney and Eigenbrode 2012). Agricultural lands may be targeted for conservation efforts that prioritize reestablishment of native species, including those adapted to fire (Nielsen-Pincus et al. 2010; Goldberg et al. 2011). This could have important ecological and social implications, especially in the Palouse Prairie-forest ecotone.

Little is known about historical fire activity in the Palouse Prairie-forest ecotone, as there are few local fire history data (Peterson 2004; Heyerdahl et al. 2008b). Daubenmire $(1942,1970)$ argued that fires were not common on the Palouse Prairie given the relatively moist conditions conducive to rapid decomposition of 
dormant grass fuel and relatively uncommon lightning. Improving our understanding of historical fire occurrence could inform conservation and restoration of the ecotone.

Wildfire risk on the prairie-forest ecotone today has been shaped by population and conservation trends that have emerged since the late nineteenth century. Intensive agriculture is widespread. Residential development in areas formerly dominated by agriculture (Pocewicz et al. 2008) can result in increased wildfire hazard as new residents change the species composition by planting perennial grasses, shrubs, trees, and, in some cases native flora (Donovan et al. 2009; Nielsen-Pincus et al. 2010). Conservation programs like the federally funded Conservation Reserve Program (CRP) and the Idaho Wildlife Habitat Incentive Program target areas of agriculturally marginal land with high soil erosion rates and prioritize increasing the habitats needed by native species (Roberts and Lubowski 2007). Pocewicz et al. (2008) found that landowners planted perennial grasses and trees under the Conservation Reserve Program in the Palouse Prairie-forest ecotone. The resulting continuous prairies adjacent to forest could facilitate fire spreading from prairie to forest, while also increasing risks for homes and other infrastructure in the ecotone. These changes in vegetation and values may make future wildfires more frequent and severe for three reasons. First, in non-urban areas, increases in human population density tend to be associated with increased probability of fire ignitions (Syphard et al. 2007), although less area may burn due to increased land fragmentation and fire suppression resources. Second, changes in land cover composition from agriculture to development and changes in agricultural practices can increase fuel availability and wildfire risk. Simultaneously, fire suppression response capacity lessens due to a lack of preparation among new residents (Paveglio et al. 2015). Third, increases in the large fire potential and overall burned area projected for the broader region in the coming decades due to climate change (e.g., Barbero et al. 2015) could mean that future fires will be a greater threat to people, homes, and timber values along the prairie-forest ecotone. Understanding historical fire and vegetation structure can inform future conservation and ecosystem management.

Understanding changes through time in the vegetation and fire of the Palouse bioregion requires multiple lines of evidence because no single record spans the timeframe of major transition in land cover from preEuropean-American settlement to the present. General Land Office (GLO) survey records provide spatial and systematic descriptions of vegetation in the 1870 s and 1880s (Bourdo 1956), just prior to intensive agriculture and other land use changes. Human population censuses and aerial photographs capture snapshots of conditions in the 1900s (Black et al. 1998). Fire scars on trees capture fire occurrence in the forests for several hundred years, but the record ends in the late 1800s when most of these trees were removed for agriculture and timber production. Modern records of fire occurrence, weather, and lightning exist for fires in recent decades but not historically (Abatzoglou et al. 2016). We combined all of these records to assess changes in the Palouse bioregion.

Our objective was to understand historical and current vegetation and fire in the Palouse Prairie-forest ecotone. We evaluated changes in land cover between the late nineteenth century and today, and we quantified historical fire history from tree rings and contrasted that with modern fire occurrence and lightning ignitions. We interpreted the implications of changing land use, fire, and conservation, now and in the future. Understanding the past and potential future of fire and vegetation in the Palouse bioregion may help us live with fire while conserving ecological values here and in similar prairieforest landscapes into the future.

\section{Methods}

Study area

Our study area focused on 286053 ha of forest-prairie ecotone within the broader 1.2 million ha Palouse bioregion (Fig. 2). We started with the Palouse bioregion (Fig. 2) identified by Bailey (1995), buffered it to $10 \mathrm{~km}$ beyond the boundary, and excluded portions south of the Clearwater and Snake rivers. Thus, our study area includes portions of Latah and Benewah counties in Idaho and Whitman County in Washington, USA. The ecotone was defined as extending $8 \mathrm{~km}$ into the forest and $10 \mathrm{~km}$ into the prairie from the existing forest edge that we hand-digitized on $1 \mathrm{~m}$ resolution aerial photographs from 2015 at a map scale of 1:50 000. The rolling hills of this bioregion are dunes of windblown loess overlying basalt with some scattered quartzite outcrops (Donaldson 1980; Barker 1981). The bioregion is bounded to the north and west by the channeled scablands that were scoured by Pleistocene floods (Bretz et al. 1956). On the rolling hills to the east, prairie grades into the forests of the granitic Bitterroot Mountains.

Monthly temperature ranges from an average minimum of $-5{ }^{\circ} \mathrm{C}$ in January to an average maximum of $29^{\circ} \mathrm{C}$ in July (1900 to 2017, Washington division 10, www7.ncdc.noaa. gov/CDO/CDODivisionalSelect.jsp, accessed 22 October 2018). Mean annual precipitation varies across the study area from $500 \mathrm{~mm}$ in the western portions of the study area to $800 \mathrm{~mm}$ near the modern edge of continuous forests in Idaho, with only a quarter of this precipitation occurring during the fire season (May to September). The area exhibits gradients in temperature and precipitation with elevation 

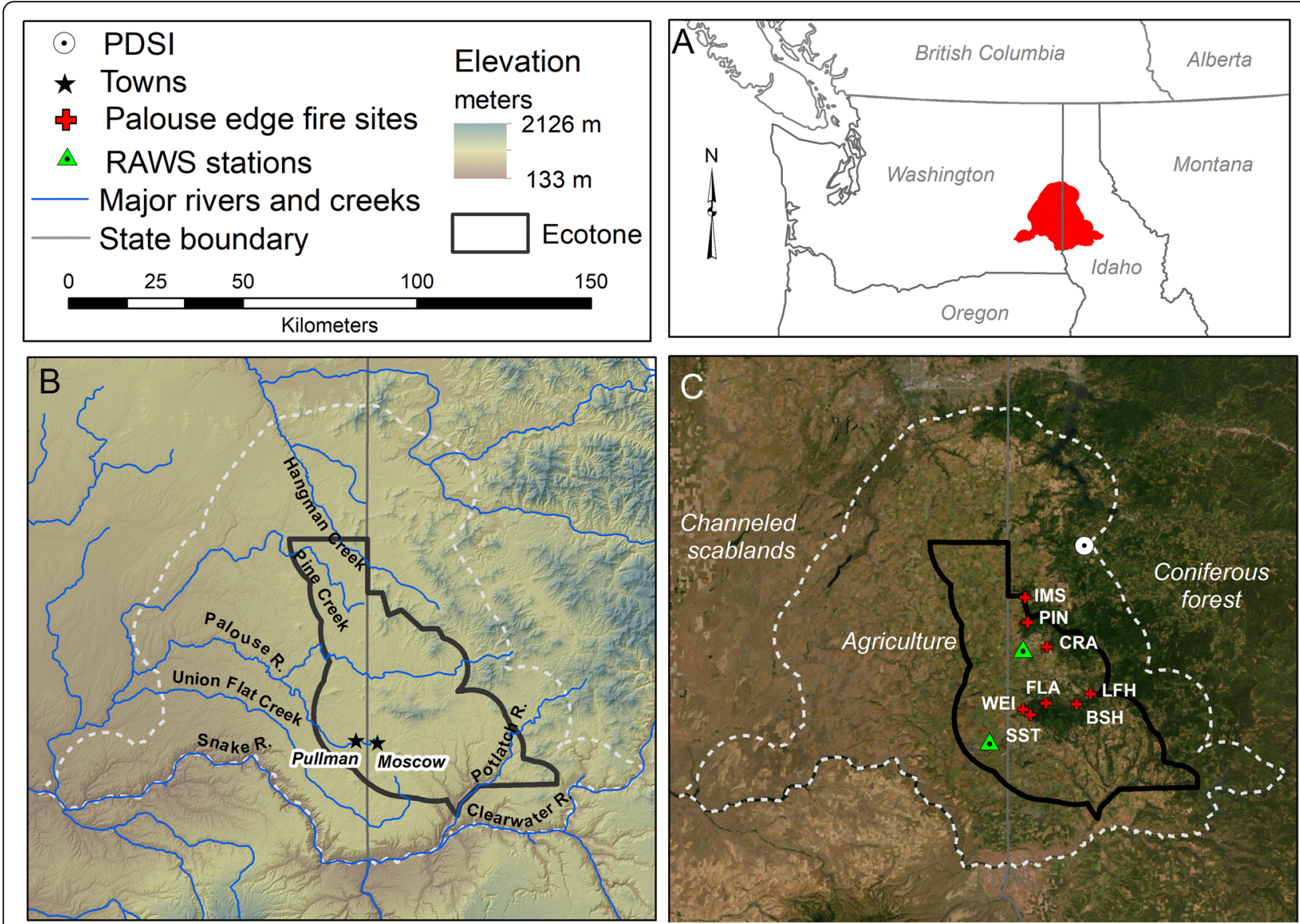

Fig. 2 (A) Study area in Idaho and Washington, USA. (B) The Palouse Prairie-forest ecotone between historical prairie and forest (black outline) with topography, streams, and towns. (C) Study was done in 2018 to 2019 within the Palouse bioregion north of the Snake and Clearwater rivers (white dashed line), here shown in an aerial photograph with current landscape cover along with the sampling sites for fire history (Table 1, red, data collected 2008 to 2019) and two Remote Automatic Weather Stations (RAWS, green)

that increases from west to east across the region. During the summer fire season, the prevailing daytime wind is from the south and southwest, although light nocturnal downslope mountain flow from the east is prevalent when synoptic-scale weather patterns are weak (Potlatch Remote Automated Weather Station, https://raws.dri.edu/cgi-bin/ rawMAIN.pl?idIPOT, accessed 14 May 2019).

Weaver (1917) described the landscape as continuous prairie grading into open, scattered pines (hereafter, pine savanna), with continuous forest at its eastern edge as elevation and precipitation increase. The prairie was historically dominated by perennial bunchgrasses, including bluebunch wheatgrass (Pseudoroegneria spicata [Pursh] Á. Löve) and Idaho fescue (Festuca idahoensis Elmer), but also supported many forbs such as arrowleaf balsamroot (Balsamorhiza sagittata [Pursh] Nutt.). Shrubs such as rose (Rosa spp. L.), common snowberry (Symphoricarpos albus [L.] S.F. Blake), black hawthorn (Crataegus douglasii Lindl.), and other shrubs occurred sporadically in the prairie. Small camas (Camassia quamash [Pursh]
Greene) was found in some of the deeper draws and in periodically wet meadows along streams (Weaver 1917; Tisdale 1961; Daubenmire 1942, 1970). Aspen (Populus tremuloides Michx.), birch (Betula spp. L.), alder (Alnus spp. Mill), balsam poplar (Populus balsamifera L.), and Engelmann spruce (Picea engelmannii Parry ex Engelm.) occurred along perennial streams and in wet draws. The savanna had similar vegetation to the prairie with the addition of scattered ponderosa pine. The forests were dominated by ponderosa pine and Douglas-fir with grass and shrub understories including many of the grass and forb species of the adjacent prairie (Daubenmire 1942, 1970).

Land cover in the Palouse bioregion has changed through time due to changes in agricultural technology, crop and timber markets, and other social trends (Black et al. 1998). The changes are readily apparent in comparisons of historical and current photographs (Fig. 3). Prior to the 1870s, Native Americans harvested small camas in the intermittent wetlands of the Palouse Prairie 

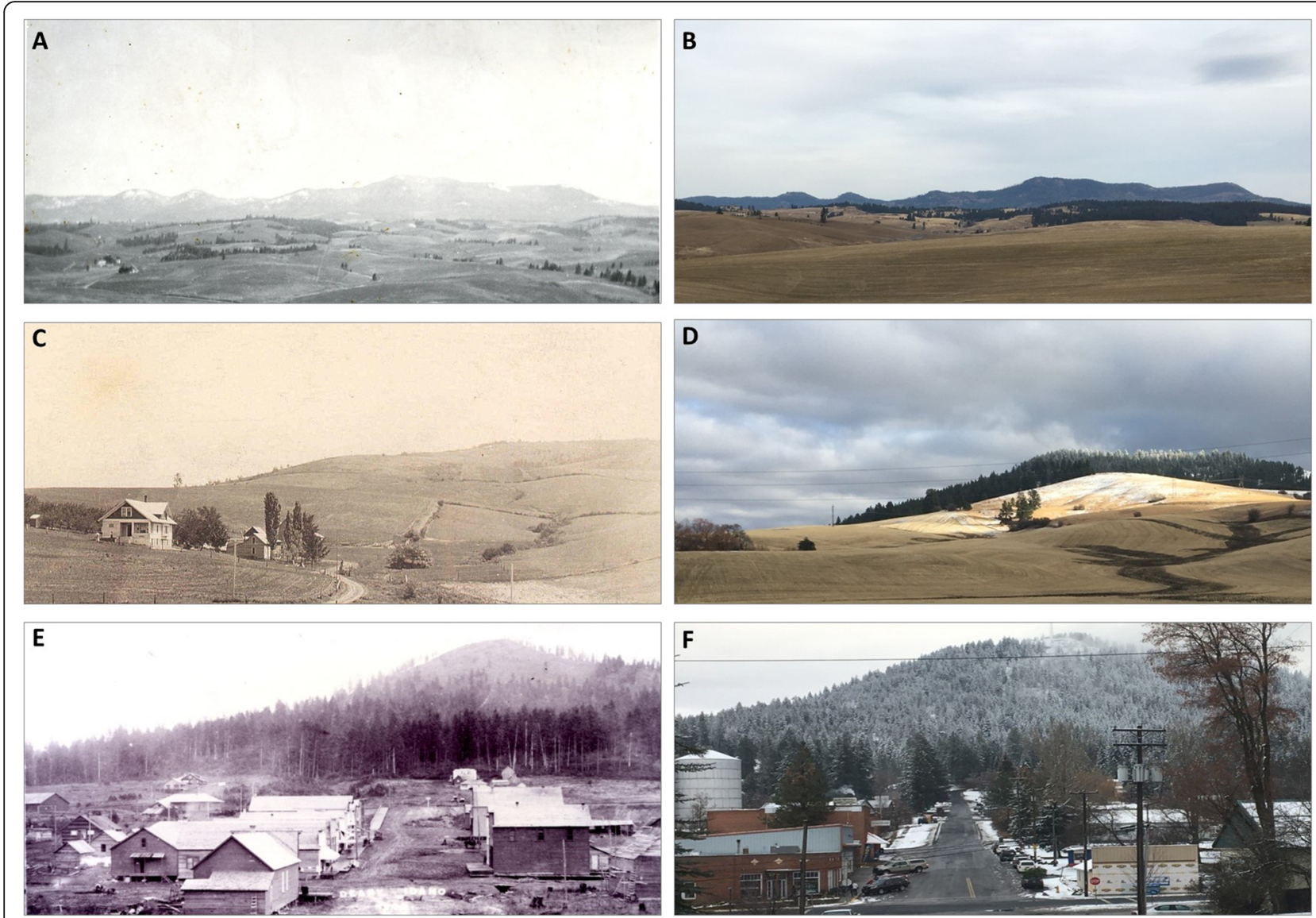

Fig. 3 Past and present landscape cover. (A) Looking north toward Moscow Mountain from Joel, Idaho, USA, in 1927 and (B) in 2019. (C) Tomer Butte, 8 km east of Moscow, Idaho, in 1913 and (D) in 2019. (E) Looking north along Main Street in Deary, Idaho, in 1910 and (F) in 2019. Photos (A) and (E) from Latah County Historical Society. Photo (C) courtesy of Patrick Curran. Photos (B), (D), and (F) by Stephen Bunting

and ranged widely in the uplands, especially after they acquired horses in the mid 1700s (Meinig 1968). Native Americans also likely purposefully ignited fire in prairies and forests (Weaver 1917; Meinig 1968). EuropeanAmerican settlement began in the 1870s and then accelerated in the following few decades. The scattered small towns were linked predominantly by roads but had little access to agricultural markets. Agriculture on the Palouse intensified dramatically following the railroad boom of the 1880s, culminating in the cultivation of nearly all arable land and the intensive monoculture of wheat by 1910 (Duffin 2007). The General Land Office surveys conducted in the decades before 1900 just predated great change as prairies were altered by agriculture and livestock grazing (Weaver 1917; Daubenmire 1942; Meinig 1968). Land cover changed early and rapidly. Farms occupied about 25\% of Latah County in Idaho and $50 \%$ of Whitman County in Washington in 1890, and by the 1930s, all arable land was farmed (Black et al. 1998). With the intensification of horse-powered agriculture (1901 to 1930), much of the Palouse Prairie was plowed or used for pasture, and wood from adjacent forests was used in local construction as well as sent to national timber markets. With increasingly intensive agriculture (1931 to 1970), farms became larger and mid-sized towns grew at the expense of smaller ones. Suburbanization in the region since 1971 included ex-urban development (Black et al. 1998) of agricultural land, along with a growing interest in conservation and restoration of native prairie (Donovan et al. 2009).

Currently, native prairie vegetation has been reduced to very small, isolated remnants (most $<2$ ha) persisting within a matrix of extensive agricultural fields of cereal grains (most commonly Triticum aestivum L.) and various pulses (Fabaceae) (Looney and Eigenbrode 2012). In some areas, these fields have recently been converted to perennial grass, or grass and tree mixtures under the CRP. This voluntary land conservation program began in 1985, is administered by the United States Department of Agriculture, and pays farmers to take agricultural lands on highly erodible soils out of production for at least 10 years. Land area in CRP varies through time but is approximately $9 \%$ of the ecotone and $19 \%$ of the Palouse bioregion based on 
LANDFIRE Existing Vegetation classified from satellite imagery (www.landfire.gov). Grasses are the predominant fuel for wildfires in both CRP and prairie remnant vegetation today (S. Bunting, University of Idaho, Moscow, Idaho, USA, personal observations). In the Palouse bioregion study area, current land cover includes $72 \%$ agriculture, $9 \%$ prairie dominated by non-native perennial grasses (CRP), $11 \%$ forest, and $<2 \%$ native prairie. The remainder includes residential development, roads, and ponds (Donovan et al. 2009).

\section{Historical records: General Land Office surveys and tree rings}

To reconstruct the location of the prairie-forest ecotone in the late 1800s, we mapped the location of bearing trees that were identified at section and quarter-section corners when the study area was surveyed between 1869 and 1893 (98\% of the 2793 GLO section corners in the ecotone with accessible records were surveyed before 1883). We read the field notes from GLO surveys of the external lines of each township, and the internal lines subdividing each township into $36 \mathrm{sec}-$ tions (Bourdo 1956) for Washington (www.blm.gov/or/landrecords/survey/yGrid_ORWA.php?state $=$ WA\&ln $=10000000$, accessed April to November 2018) and Idaho (glorecords. blm.gov/default.aspx, accessed April to November 2018). When original surveys were incomplete for townships, we used field notes from later surveys ( $2 \%$ of the points), and we excluded the Coeur d'Alene Indian Reservation as it was not surveyed until many years later. GLO surveyors recorded species and stem diameter at breast height $(1.3 \mathrm{~m})$ plus direction and distance from the section corner for up to four bearing trees within $60.2 \mathrm{~m}$ of each section corner with one in each quadrant (up to two trees for each quarter section corner, one in each half). Where there were no trees in a quadrant (section corners) or half (quarter section corners), they dug a pit, instead, from which they recorded direction and distance to the corner (Bourdo 1956). We categorized each section corner and quarter section corner into one of three classes: (1) those with no trees as prairie, (2) those with 25 to $50 \%$ of possible bearing tree locations with trees as

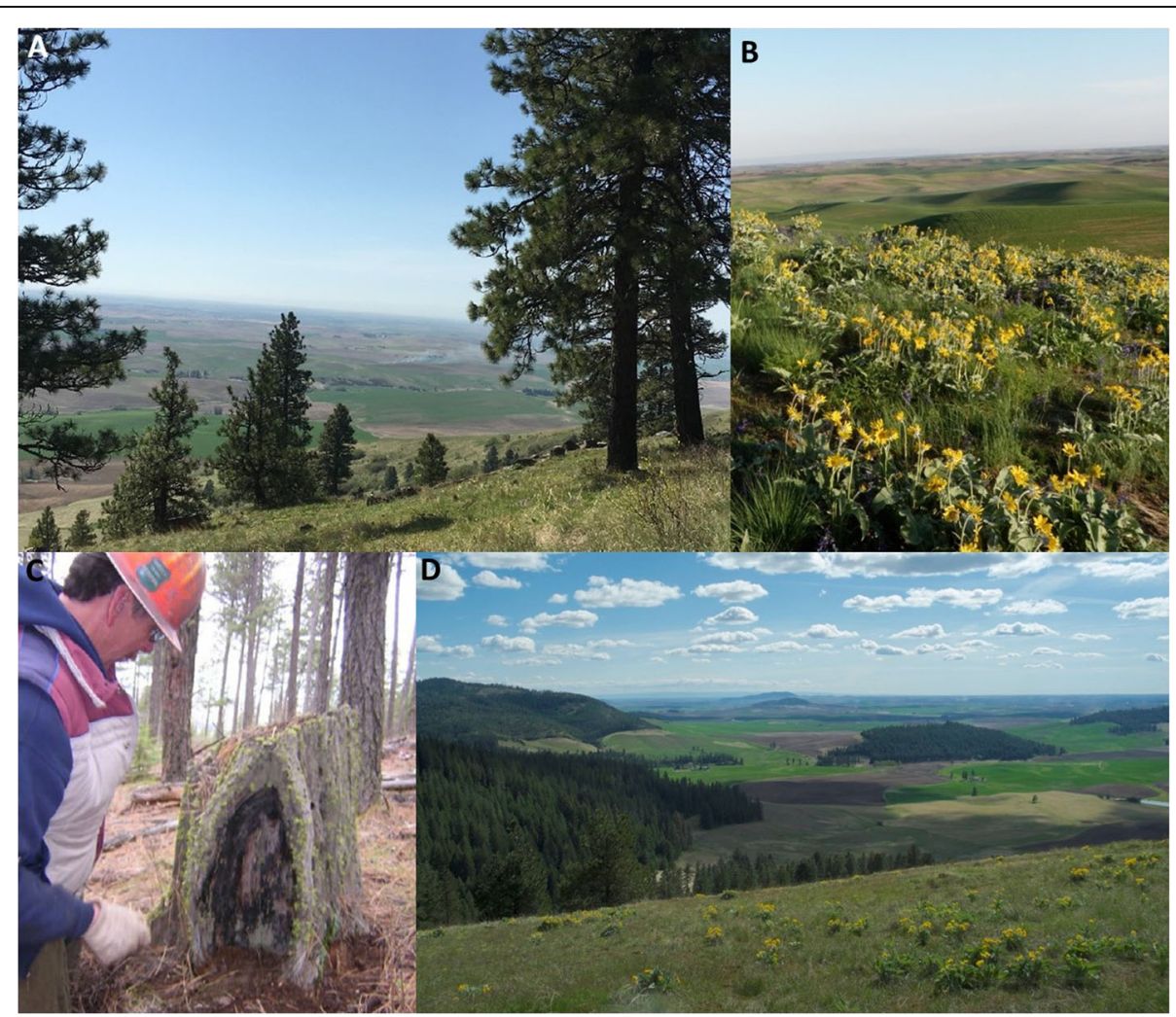

Fig. 4 (A) Scattered ponderosa pine trees in pine savanna adjacent to the Palouse Prairie today. (B) Plant communities were dominated by dense bunchgrasses mixed with some forbs and shrubs as in this 2018 picture of remnant prairie vegetation in Kamiak Butte County Park, Whitman County, Washington, USA. Grass would have carried fires through both the Palouse Prairie and the pine savanna. (C) One of the old fire-scarred ponderosa pine stumps that we sampled to reconstruct fire history. (D) The rolling hills of the Palouse Prairie are now dominated by intensive agriculture with fields of wheat and legumes separated by roads. Adjacent forests are dense mixed-conifer forests. There are few remnants of the once extensive Palouse Prairie and pine savanna. Photographs taken by: (A) Penelope Morgan in 2018, (B) Stephen Bunting in 2018, (C) Max Nielsen-Pincus in 2008, and (D) James Riser in 2017. Photos (A), (B), and (D) are from locations in Whitman County, Washington. Photo (C) is from a location in Latah County, Idaho, USA, in 2008 
savanna, and (3) those with 75 to $100 \%$ of possible bearing tree locations with trees as forest. For all locations, we calculated percent pine and assumed for prairie and savanna that these were ponderosa pine (Additional file 1). We recognized that trees may have been previously removed by fire or by people, but we expected survey notes to include mention of evidence of any fire or harvesting. The GLO data we used are available in Additional file 2.

To reconstruct historical fires, we sampled firescarred trees (Fig. 4). We analyzed historical fire occurrence at eight sites along the forested eastern ecotone of the Palouse bioregion (Fig. 2), including five sites that we sampled for this study and three sites that were sampled in a similar manner for other studies (Table 1). We targeted sites with numerous firescarred trees that were historically dominated by ponderosa pine. The sites were similar in elevation $($ mean \pm standard deviation $=1026 \pm 95 \mathrm{~m})$, on south- or southwest-facing aspects with mostly gentle slopes ranging from 0 to $40 \%$, and most had been logged. The distance between sites averaged $19 \pm 10$ $\mathrm{km}$. We used a chainsaw to remove fire-scarred partial sections from those trees or stumps with the greatest number of well-preserved visible scars (Arno and Sneck 1977), sampling $13 \pm 10$ trees per site across areas of $11 \pm 8$ ha (Table 1 ). We sanded the fire-scarred sections until we could see the cell structure with a binocular microscope. We assigned calendar years to tree rings by visually crossdating ring widths using chronologies that we developed from trees in our plots, occasionally assisted by cross correlation of measured ring-width series (GrissinoMayer 2001). We identified the calendar year in which each scar formed as the year of fire occurrence and noted its intra-ring position (earlywood, latewood, or ring boundary). For scars that formed on the boundary between two rings, we assumed that historical fires burned during the late summer or fall season as do current fires in the study area (Bartlein et al. 2008) and assigned ring-boundary scars to the preceding calendar year. In addition to fire scars, we obtained a small amount of supporting evidence of fire from eroded fire scars (about 5\% of all fire dates), those with much of the overlapping, curled woundwood rings destroyed by subsequent fires or rot. At each site, we combined the fire-scar dates from all trees into a composite record. From these composites, we identified fire years as those in which at least two trees had been scarred; however, we relaxed this constraint to one scarred tree for Basalt Hill and Leef's Hill, at which only three or four trees were sampled. We identified recording years as those for which at least two trees had scarred at least once. Although scars dated from 1599 to 1923, we analyzed fire history only from 1650 to 1900 , the period when most of the sites were recording fire (i.e., had a least one fire-scarred tree).

\section{Current vegetation, lightning, and fire}

To infer the potential for historical and current fires to ignite either by people or by lightning, we analyzed lightning occurrence and lightning-caused fires over

Table 1 Site characteristics and amount of evidence used to reconstruct fire histories at the eastern edge of the Palouse Prairie ecotone in Idaho, USA. Recording years are those for which at least two trees had scarred at least once. Unless drawn from other studies as noted, these data were based on crossdated fire scars from partial tree sections sampled in 2008 (Crane Creek, Pine Creek, and Weitz) or 2018 to 2019 (Iron Mountain South and Southside Trail)

\begin{tabular}{|c|c|c|c|c|c|c|c|c|c|c|}
\hline $\begin{array}{l}\text { Fire history } \\
\text { site name }\end{array}$ & $\begin{array}{l}\text { Site } \\
\text { code }\end{array}$ & $\begin{array}{l}\text { Latitude } \\
\left({ }^{\circ}\right)\end{array}$ & $\begin{array}{l}\text { Longitude } \\
\left({ }^{\circ}\right)\end{array}$ & $\begin{array}{l}\text { Elevation } \\
(\mathrm{m})\end{array}$ & $\begin{array}{l}\text { Area } \\
\text { sampled } \\
\text { (ha) }\end{array}$ & $\begin{array}{l}\text { Number } \\
\text { of trees } \\
\text { crossdated }\end{array}$ & $\begin{array}{l}\text { Number } \\
\text { of fire scars }\end{array}$ & $\begin{array}{l}\text { Recording } \\
\text { years }\end{array}$ & $\begin{array}{l}\text { Land } \\
\text { ownership }\end{array}$ & Source \\
\hline Basalt Hill & $\mathrm{BSH}$ & 46.84083 & -116.7814 & 992 & 13 & 3 & 72 & 1689-1886 & $\begin{array}{l}\text { University of } \\
\text { Idaho } \\
\text { Experimental } \\
\text { Forest }\end{array}$ & Peterson 2004 \\
\hline Crane Creek & CRA & 46.98736 & -116.89421 & 954 & 13 & 10 & 163 & $1678-1890$ & private & This study \\
\hline $\begin{array}{l}\text { Flannigan } \\
\text { Creek }\end{array}$ & FLA & 46.84527 & -116.89833 & 947 & 28 & 25 & 556 & 1599-1925 & private & $\begin{array}{l}\text { Heyerdahl et al. } \\
2008 a, 2008 b\end{array}$ \\
\hline $\begin{array}{l}\text { Iron Mountain } \\
\text { South }\end{array}$ & IMS & 47.11604 & -116.97550 & 1134 & 3 & 20 & 377 & 1598-2015 & $\begin{array}{l}\text { McCroskey } \\
\text { State Park }\end{array}$ & This study \\
\hline Leef's Hill & $\mathrm{LFH}$ & 46.86683 & -116.72934 & 886 & 2 & 4 & 42 & 1630-1992 & $\begin{array}{l}\text { University of } \\
\text { Idaho } \\
\text { Experimental } \\
\text { Forest }\end{array}$ & Peterson 2004 \\
\hline Pine Creek & PIN & 47.05164 & -116.96543 & 1138 & 7 & 9 & 171 & 1619-2005 & private & This study \\
\hline Southside Trail & SST & 46.81181 & -116.95470 & 1110 & 11 & 18 & 391 & 1735-1930 & private & This study \\
\hline Weitz & WEl & 46.82721 & -116.98500 & 1043 & 14 & 8 & 187 & $1671-1895$ & private & This study \\
\hline Total & & & & & & 97 & 1959 & & & \\
\hline
\end{tabular}


both the Palouse bioregion (1 166211 ha) and the surrounding area for context $\left(46.25^{\circ}\right.$ to $48^{\circ} \mathrm{N}, 116^{\circ}$ to $118^{\circ} \mathrm{W} ; 2949727 \mathrm{ha}$ ) from 1992 to 2015 . We restricted analysis to the months of May to September, during which $92 \%$ of fires occurred (62\% started in July to August). Cloud-to-ground lightning strike data from 1992 to 2009 were acquired from the National Lightning Detection Network and strike data from 2010 to 2015 were acquired from the North American Precision Lightning Network (http://toasystems.com/) and processed following Abatzoglou et al. (2016). We obtained dates and locations of lightning-caused fires from the Fire Program Analysis fire occurrence database (Short 2017). Approximately 30\% of fires with known cause were attributed to lightning. We aggregated both the lightning and lightning-caused fire occurrence datasets to a common $4 \mathrm{~km}$ grid. We estimated overall lightning-ignition efficiency (LIE) as the ratio of the number of lightning-caused fires to the number of cloud-to-ground lightning strikes (Abatzoglou et al. 2016). LIE exhibits seasonal and interannual variability due to variations in fuel moisture and abundance; however, we considered a single LIE for each 4-km grid cell by tabulating the total number of lightning strikes and lightning-caused fires ignited within each grid cell for May to September, 1992 to 2015. We aggregated LIE by land cover class to assess differences in ignition potential. Existing Vegetation Types (EVT) from LANDFIRE were grouped into 10 broad classes to be consistent with related studies (https://landfire.gov/, accessed 2 May 2018; Johnson 1999; Nielsen-Pincus et al. 2010; Additional file 3). Lightning detection is generally considered accurate to within $500 \mathrm{~m}$ in the western USA (Cummins et al. 1998), making it unfeasible to attribute the exact vegetation type to each lightning strike or fire. To overcome this mismatch, we aggregated $30 \mathrm{~m}$ EVT classes to the common $4 \mathrm{~km}$ grid and classified grid cells that had at least $33 \%$ of a given land cover class (i.e., some grid cells had two land cover types). We used the resultant $4 \mathrm{~km}$ gridded data of land cover classes, lightning strikes, and lightning-caused fires to estimated LIE for the EVT classes.

\section{Results}

\section{Historical records: General Land Office surveys and tree rings}

In the 1870 s and 1880 s, GLO surveyors described a landscape that greatly differs from today's agriculturally dominant landscape. The ecotone was a matrix of prairie with extensive savanna and some forest. A typical quote from surveyors' notes about the prairie was:

Land is nearly all of the best quality for farming purposes. Dark mellow loam soil thickly covered with bunchgrass, sunflower, rose brush and a great variety of weeds and flowers with camas and ryegrass in the bottoms... All can be plowed and cultivated... numerous springs and spring branches... About 20 settlers [in the township]... (Edson Briggs, 1875; subdivisional survey field notes for T14N R44E Willamette Meridian, Washington Territory, from https://www.blm.gov/or/landrecords/ survey/yGrid_ORWA.php?state $=$ WA\& $\ln =10000000$, accessed April to November 2018.)

Pine savanna was extensive, covering $16 \%$ of the area (450 of 2793 section and quarter section corners had some but few trees; Fig. 5). Surveyors noted scattered trees in many areas, such as, timber is scattering pine almost might be called prairie (Henry Meldrum, 1871; subdivisional survey field notes for T41N R4W Boise Meridian, Idaho Territory). A typical note from the forest was, Heavily timbered with fir, pine and tamarack and undergrowth of buckbrush (Herman Gradon, 1887; subdivisional survey field notes for T42NR4W, Idaho Territory). This quote and the previous quote are from the field notes from GLO surveys of Idaho (https:/glorecords.blm.gov/default.aspx, accessed April to November 2018). In some stream bottoms, surveyors recorded aspen, birch, alder, and balsam poplar (sometimes referred to as black cottonwood or balm). Surveyors also noted the presence of pine along the bluffs of the Palouse River. Some townships had settlers and there were two small sawmills in the area when surveyed in 1883. More than half of the 2793 GLO points were then prairie; this is now dominated by agriculture with some CRP and residential development (Fig. 5). Less than half of what was extensive pine savanna is now forest or shrubs, with the remainder now in agriculture, CRP, and developed land cover (Figs. 5 and 6). None of this is savanna. Forests covered $12 \%$ of the ecotone and this is still mostly forest (Fig. 6).

We removed fire-scarred partial sections from 107 trees (average of two partial sections per tree). All were ponderosa pine, and most were stumps. We could not crossdate sections from $9 \%$ of the sampled trees and so excluded them. From the 97 crossdated trees, we identified 1906 fire scars that occurred during the analysis period (1650 to 1900), from which we identified $29 \pm 9$ fire years. Fires were historically frequent, occurring on average every 5 to 8 years at most sites, but every 13 years at Leef's Hill, which had few recording trees after 1800 (Fig 7). Detailed fire charts for each site are shown in Additional file 4. We were able to determine the intraring position of $57 \%$ of the fire scars. Of these, 32 to $58 \%$ per site occurred during the growing season. Our fire-scar dates and associated metadata are available from the International Multiproxy Paleofire Database (www.ncdc. noaa.gov/paleo/impd/paleofire.html). Synchronous fires (those occurring at three or more sites in the same year) 


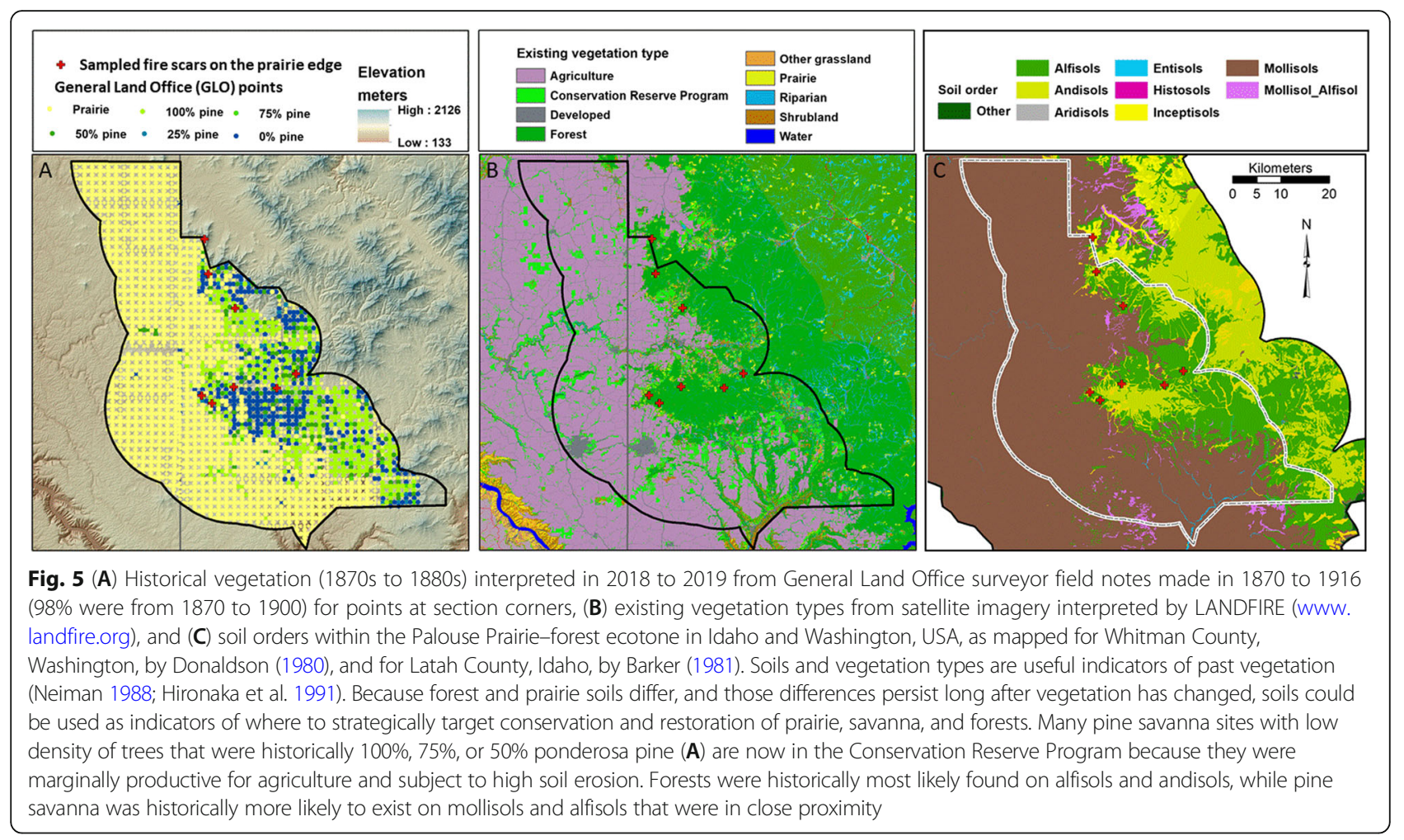

tended to occur during years with warm, dry summers (data not shown).

\section{Current vegetation, lightning, and fire}

Modern lightning-caused fires are much less common on the Palouse Prairie than in the surrounding areas (Fig. 8). The mean cloud-to-ground lightning strike density over the Palouse bioregion is 0.94 strikes $\mathrm{km}^{-2}$ $\mathrm{yr}^{-1}$. This is slightly lower than in the mountains of central Idaho to the east and the Blue and Wallowa mountains to the south, but higher than regions to the west over the lower-elevation Columbia Plateau. These lightning strikes rarely ignite fires in the Palouse bioregion. A total of 285 lightning-caused fires were reported from 1992 to 2015 in the Palouse bioregion, with 0.93 lightning-caused fires per $1000 \mathrm{~km}^{2} \mathrm{yr}^{-1}$. The frequency of lightning-caused fires immediately outside the bioregion to the north, south, and east is notably higher, more so than would be expected based strictly on lightning frequency. However, there are significant differences in LIE among land cover classes within the Palouse bioregion, with LIE of 0.3 fires per 1000 strikes in agricultural land cover compared with 1.1 and 2.4 fires per 1000 strikes in shrubland and forest land cover, respectively. Unfortunately, there were not enough contiguous CRP or prairie pixels for robustly estimating LIE for those land cover classes. Relatively few fires burned recently in the Palouse bioregion compared to surrounding area (Fig. 8). In the Palouse bioregion, recent records (1992 to 2015) include 2359 fires ( 412 or $17 \%$ of these fires were ignited by lightning) that burned a total of 75474 ha $(6.5 \%$ of the area). Nearly half of these fires occurred during the drought year of 2015 when fires were widespread in Idaho and Washington.

\section{Discussion}

\section{Conservation implications of land cover change}

Human values have and will continue to change the Palouse Prairie-forest ecotone in southeastern Washington and west-central Idaho, USA, and other similar forestprairie ecotones. Since the 1870s and 1880s, the Palouse Prairie has been altered by humans who converted the landscape matrix from prairie, pine savanna, and mixedconifer forests to today's intensive agricultural lands with isolated remnants of prairie, no pine savanna, and forests that have become denser and likely different in their composition of trees and shrubs (Figs. 4, 5 and 6). Across the Latah and Benewah counties portions of this region, Pocewicz et al. (2008) used historical trends and landowner surveys to predict that the number of residential housing units will increase at the expense of agricultural and forest cover. Residential development has led to conversion from agricultural fields to other land cover (Pocewicz et al. 2008) with conservation implications (Goldberg et al. 2011). Our data provide a longer time frame for evaluating land cover change now and in the future. 


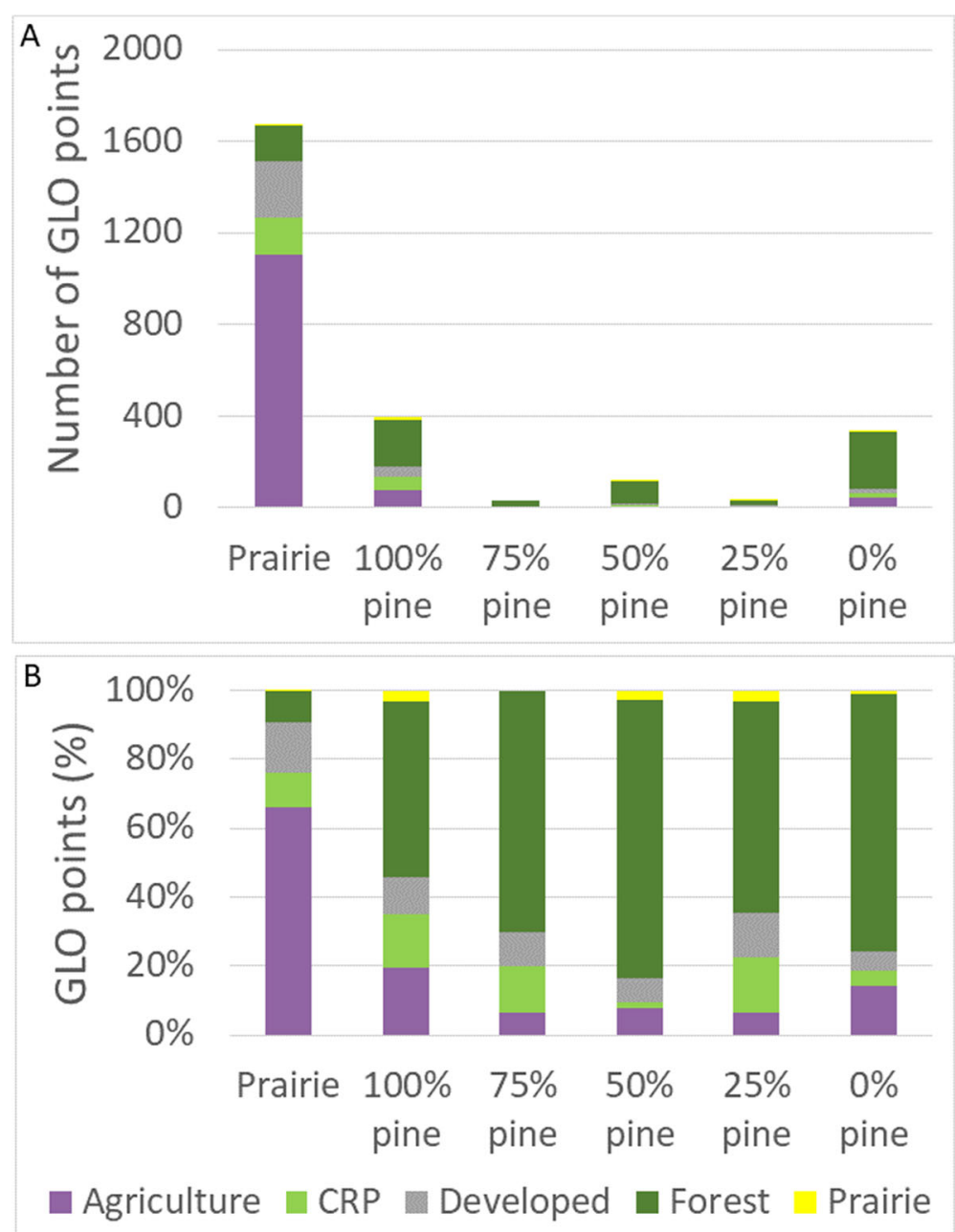

Fig. 6 Vegetation change in the Palouse Prairie-forest ecotone. (A) Number and (B) percentage of each of 2793 General Land Office (GLO) section corner points in the ecotone showing historical vegetation class (horizontal axis) with existing vegetation type class. Prairie was most abundant in the ecotone (>1500 of 2793 GLO section corner points); much of the prairie is now agriculture, in the Conservation Reserve Program (CRP), or developed. Surveyors recorded 100\% of the bearing trees as pine (we judged these to be ponderosa pine) at 450 section corners and now about half of those corners are forested

Changes in local social values along the ecotone that favor aesthetics and natural diversity (Donovan et al. 2009) will change the ecological landscape. Low productivity sites for agriculture, for example, may be more likely to be converted from intensive agriculture to other land uses (Nielsen-Pincus et al. 2010), with implications for soil erosion, vegetation, and fire. Ongoing conservation and restoration efforts are also influencing the ecotone. Although soils and topography (Fig. 5) are useful in strategically prioritizing vegetation restoration and management of prairie, savanna, forest, and wetlands, small changes in incentives (such as CRP funding) or technical assistance can spur substantial change in uses on marginally productive agricultural and forest lands (Nielsen-Pincus et al. 2010). Conservation practices have reduced soil erosion on the Palouse Prairie (Barker 1981) and benefited wildlife and other values nationwide (Roberts and Lubowski 2007). Changes in social values occurring among residential landowners or others interested in restoring prairies, forests, and intermittent wetlands due to their greatly reduced extent and ecological values also influence change along the ecotone, but increased restoration may come with opportunity costs (Donovan et al. 2009). Restoring some historical land covers like prairie has ecological and social benefits on the Palouse Prairie (Nielsen-Pincus et al. 2010; Goldberg et al. 2011), but restoring surrounding vegetation may also increase the risk of exposure of homes or other human values to wildfire. Restored pine savannas could serve as shaded fuel breaks 


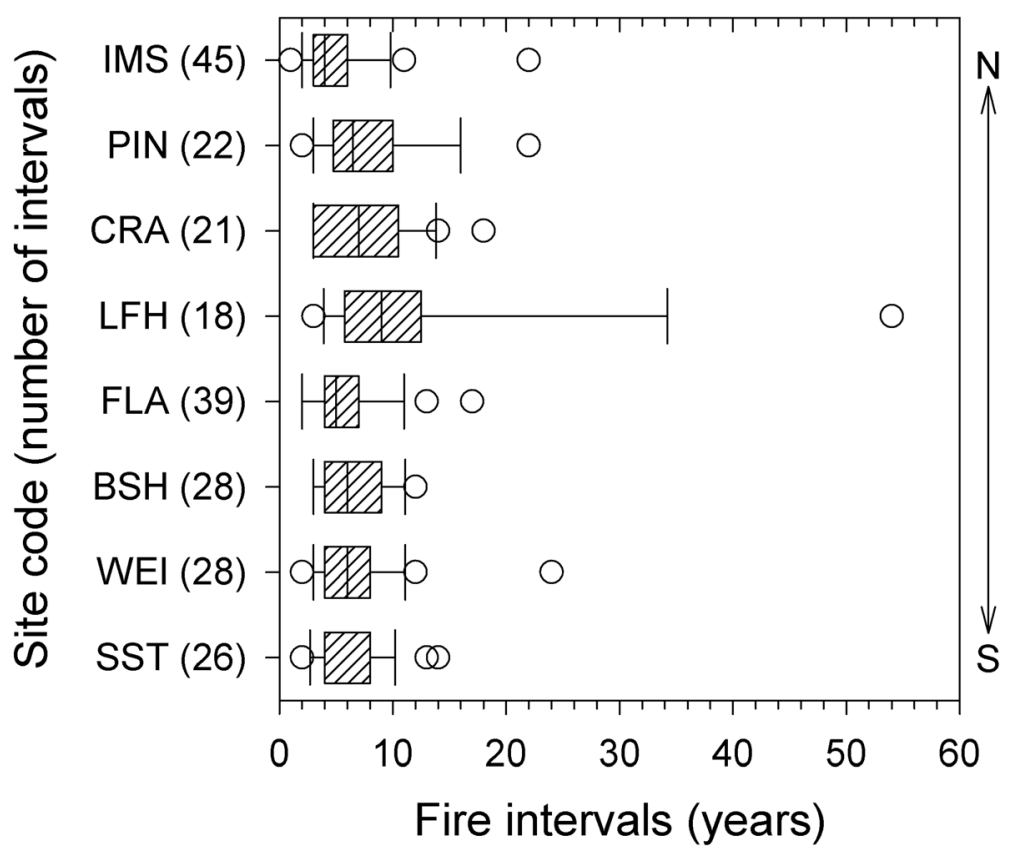

Fig. 7 Fire frequency at the forested eastern edge of the Palouse Prairie in Idaho, USA. The sites (Table 1) are arranged from north at the top to south at the bottom. Composite fire intervals were computed over $9 \pm 5$ ha per site, during the analysis period from 1650 to 1900 . Site codes on the vertical axis are followed by the number of fire intervals reconstructed during the analysis period. The boxes enclose the 25th to 75th percentiles and the whiskers enclose the 10th to 90th percentiles of the distribution of intervals. The vertical line across each box indicates the median fire interval, and all values falling outside the 10th to 90th percentiles are shown as circles

to aid firefighters in protecting people and property, and forest density reduction to foster historical pine savanna-like conditions could provide timber value to local communities while benefitting many bird species (K. Dumroese, USDA Forest Service, Rocky Mountain Research Station, Moscow, Idaho, USA, personal communication). Mountain Bluebirds (Sialia currucoides Bechstein), the state bird of Idaho, could benefit from nest sites in large live and dead trees near open savanna or prairies where they feed. The Idaho State Wildlife Plan (IDFG 2015) identified open ponderosa pine forests as important habitat to several wildlife species of greatest conservation need, including Great Gray Owl (Strix nebulosi Forster), Lewis's Woodpecker (Melanerpes lewis Gray), White-headed Woodpecker (Picoides albolarvatus Cassin), and Olive-sided Flycatcher (Contopus cooperi Swainson).

\section{Fires were historically frequent in the Palouse bioregion} Fires were historically quite frequent in the Palouse prairie-forest ecotone, which is consistent with what is known for other prairies (Samson and Knopf 1994) and in prairie-forest ecotones elsewhere (Arno and Gruell 1983; Brown and Sieg 1999; Kitzberger 2012; Harvey et al. 2017). We have two reasons to think fires were also historically frequent in the Palouse Prairie. First, the climate is conducive to biomass production and drying with warm temperatures and infrequent precipitation from June to September, allowing fuels to be receptive to carrying fire during mid to late summer. Ponderosa pine-dominated forests in the broader region have a history of frequent fires (Heyerdahl et al. 2001; Heyerdahl et al. 2008b; Morgan et al. 2008; Whitlock et al. 2008; Morgan et al. 2014), with widespread fires in warm, dry summers following warm springs (Heyerdahl et al. 2008b; Morgan et al. 2008). Second, our prairie-forest ecotone sites had grass fuels and they are adjacent to and downwind of historically extensive prairies with their rolling topography and continuous fuel that likely increased fire frequency at the prairie-forest interface. Our observed historical fire occurrence was not greatly different than that of many forested sites in the northern Rockies documented by Heyerdahl et al. (2008a, 2008b). Many of their sites (Additional file 4) were similarly adjacent to and upslope from prairie vegetation. Continuous prairie vegetation, high biomass production, rolling topography, weather conducive to fire spread over many days, and prevailing southwesterly winds likely contributed to frequent fires that spread eastward from the prairie into the pine savanna and forested regions. With a long dry season, abundant grass and shrub fuels in the prairie, savanna, and forest, and few barriers to fire spread, many fires likely grew large when conditions were conducive for fire spread. Thus, fires likely spread 


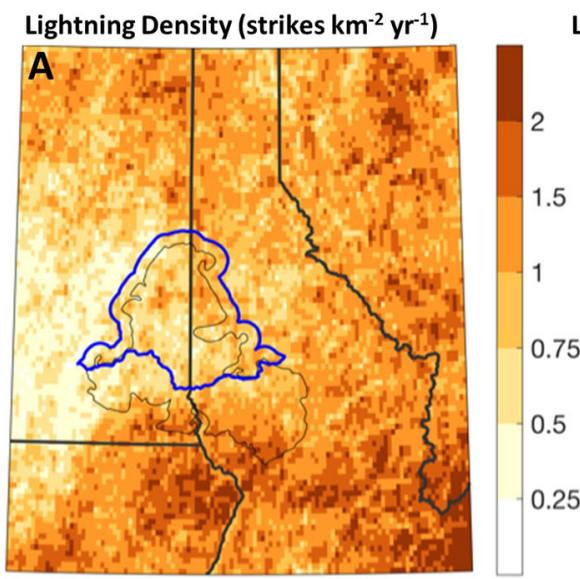

Lightning-caused Fire Density (fires $100 \mathrm{~km}^{-2} \mathrm{yr}^{-1}$ )
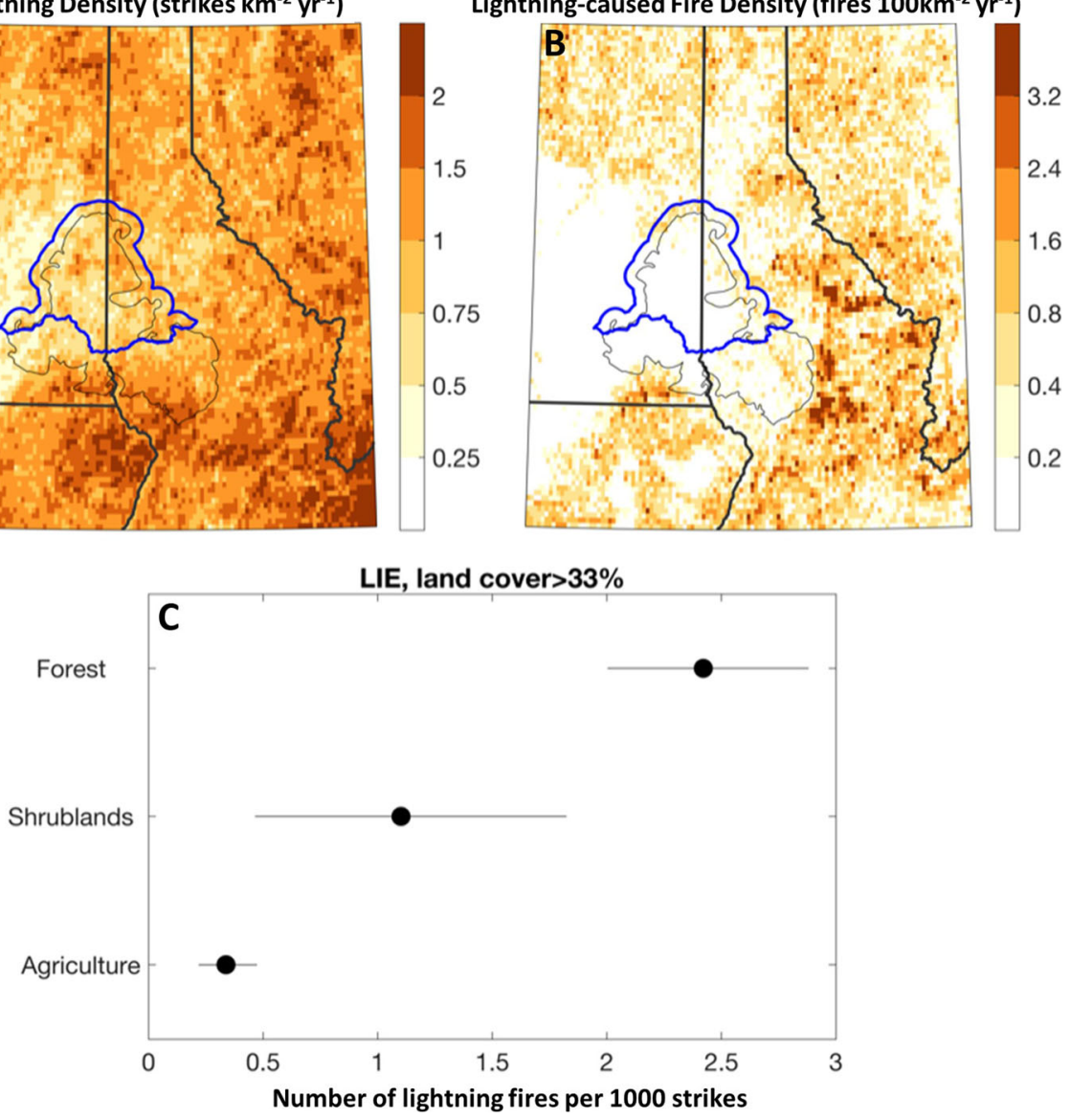

Fig. 8 (A) Warm season (May to September) lightning strike density (strikes $\mathrm{km}^{-1} \mathrm{yr}^{-1}$ ) averaged from 1992 to 2015, and (B) lightning-caused fire density (fires per $100 \mathrm{~km}^{2} \mathrm{yr}^{-1}$ ) from 1992 to 2015 for the mapped area within Idaho, Washington, Oregon, and Montana, USA. The black lines in (A) and (B) are borders of Idaho (center), Washington and Oregon are to the west, and Montana is to the east. The blue line is our study area defined as the Palouse bioregion north of the Snake and Clearwater rivers, while the light gray boundary outlines the entire Palouse bioregion as mapped by Bailey 1995. (C) Mean (black dot) and 95\% confidence interval around the mean (gray bar) Lightning Ignition Efficiency (LIE) for three existing vegetation types that each occupy more than $33 \%$ of the mapped area

into forest from prairie, and along the prairie-forest ecotones (Conver et al. 2018). This historical ecological context helped to shape the land cover-the location, structure, and composition of prairie, savanna, and forest-described by GLO surveyors. For example, by killing smaller-diameter trees but sparing larger-diameter trees, frequent low-severity fires would help to maintain the open pine savanna. In addition, surface fires consume pine litter and downed woody debris, contributing to the maintenance of a productive and diverse herbaceous and shrub component.

The roles of people in the landscape were also important. Around the world, people have always used fire (Bowman et al. 2011), and their use of fire is part of the fire history and ecology of many ecosystems. We cannot know the proportion of historical fires that were ignited by people because neither the locations of Native American encampments and travel corridors, nor their traditional vegetation and fire management methods are well documented in the Palouse bioregion. Although Bartlein et al. (2008) found that human-ignited fires occurred both earlier and later than lightning-caused fires, the intra-ring position in our fire history samples was variable and showed no distinct temporal pattern. Harvey et al. (2017) attributed local fires (those not synchronous across all sites) to people, but we did not have enough sites to draw similar conclusions. Further, we were not convinced that all lightning fires were large, and that all peopleignited fires were small. Ideally, we need sites near and far from the prairie edge and near and far from human-use areas (e.g., Barrett and Arno 1982) to be able to assess the importance of human-caused fires historically. 
The decrease in fire occurrence in late 1800 s to almost no fire in the 1900s is consistent with the increase of agriculture and roads, the introduction of livestock grazing that came with Euro-American settlement, the reduction in Native Americans present to ignite fires, and the advent of aggressive fire suppression efforts and technology. With the advent of intensive agriculture and "clean farming" (Black et al. 1998), agricultural fields now extend from roadbed to roadbed. Many of the fields are bare soil soon after harvesting. Remnant prairie patches are very few, small, and isolated, and therefore vulnerable to invasive weeds with or without fire (Looney and Eigenbrode 2012). Few of these remnants have burned in recent times.

Although fire suppression is currently aggressive and largely effective, especially given high road density and rapid response from local fire departments, it may not always be so. Currently, many fires are ignited by people and, with expanding residential development and human populations, this trend is likely to continue. Increasingly, farmers are using reduced tillage that leaves burnable residue in agricultural fields in late summer and fall, and grass fuels are abundant in lands enrolled in conservation programs. Furthermore, people often prefer perennial vegetation around homes. This juxtaposition of changing agricultural practices, residential development, and prairie restoration and conservation could renew the fuel continuity that historically carried fires into and along these ecotones, especially as these lands and their fuels are all increasingly contiguous with each other and adjacent forests. Although roads and plowed agricultural fields will continue to serve as both barriers to fire spread and access points for fire suppression, changing land use and increasing residential development in the region will continue to change the land cover and may increase the likelihood that fires will impact homes and forests. To prepare for these impacts, community fire leaders are networking across the USA with local scientists to translate the latest understanding of local historical and likely future fire behavior to develop adaptive strategies to minimize risk. Towards that end, we have interacted with local community groups in the Palouse bioregion, offering presentations and leading field tours in places where people are managing for prairie, pine savanna, and forest, using both mechanical and prescribed fire treatments.

Although more data from more sites with more samples, and samples collected systematically over larger areas could strengthen our conclusions about historical fires and the landscape context, intensive land use at this prairie-forest ecotone has destroyed much of the fire-scarred tree record. Similarly, most prairies and adjacent forests elsewhere have been greatly altered by land use. The GLO records were useful for mapping prairie versus savanna versus forest, but less useful for quantifying the degree to which forest composition has changed within areas that were and still are forested because the bearing trees chosen by surveyors may or may not be representative of the surrounding forest. Likely, the area in savanna is underestimated, for although we can be confident of savanna sites for section corners with very few trees, surveyors described some areas as having "scattering pine" for corners we designated as prairie as they had no bearing trees within $60.2 \mathrm{~m}$. Characterizing the land cover change for different soils and topographic setting (Fig. 5) would increase understanding of the social factors that influenced changing land uses through time, and could guide future restoration and conservation strategies.

\section{Conclusions}

Ecotones, such as prairie-forest edges, are ecologically important, and they are greatly affected by changing climate, fire, and land use (Kitzberger 2012; Harvey et al. 2017). Using GLO survey data, we were able to quantify the historical extent of prairie and pine savanna that has since been largely converted to farmland. Tree density increases and forest structure changes in the absence of fire, and tree encroachment into prairies occurs unless limited by climate or disturbance. These environmental changes also have implications for economic, as well as recreation, biodiversity, wildlife, and other conservation values (Nielsen-Pincus et al. 2010; Goldberg et al. 2011; Harvey et al. 2017).

Changes in land use and subsequent vegetation may result in a landscape more conducive to fire ignition and spread. Although current fire suppression efforts are very effective, changing climate and increasing residential development may challenge future fire management effectiveness. Weather remains conducive for fires and the already long fire seasons are lengthening across the western USA (Westerling 2016). At the same time, there is increasing interest in conservation and restoration of native prairie, forests, and intermittent wetlands (and hopefully savanna now that we quantified the historical extent), and using fire to manage native vegetation. Fischer et al. (2016) identified the types of changes occurring in the social and ecological dynamics of the Palouse bioregion as contributors to the socio-ecological pathology of wildfire risk, where humans intolerant to fire foster fire-prone ecological changes.

Understanding the historical role of fire in the Palouse Prairie, pine savanna, and adjacent forests could inform twenty-first century conservation, restoration, and management strategies for these rare ecosystems, as well as risk reduction efforts for the changing human 
population and landscape cover. More frequent and severe fires will threaten people, homes, timber, and other values at the prairie-forest ecotone. The climatic, vegetation, and human dynamics that drove historical fire regimes may hold important lessons for future adaptation.

\section{Supplementary information}

Supplementary information accompanies this paper at https://doi.org/10. 1186/s42408-019-0061-9.

Additional file 1. The Public Land Survey System with corners visited by the General Land Office (GLO) surveyors between 1869 and 1910 (98\% in 1870s and 1880s); we interpreted their field notes in 2018 to 2019. (A and $\mathbf{B}$ ) Each township had 36 sections, each 1 mile $\times 1$ mile. (C) At each section corner, surveyors identified one bearing tree by species within $60.2 \mathrm{~m}$ in each of four quadrants, and at quarter corners, surveyors identified one bearing tree within $60.2 \mathrm{~m}$ in each of two sides of the lines, or they dug pits if there were no bearing trees available. We recorded as prairie those corners that had no trees. For the corner with only one bearing tree, a pine, we recorded 25\% trees that were 100\% pine. This section and township were described as having "scattering pine." Full data, including descriptions, are in supplementary material for this paper (Additional file 2). To give each corner a unique identifier in the data file, we identified each corner by Township, Range, Section number and either $C$ (southwestern section corner) or B (western quarter corner, 0.5 mile north of $C$ ) or $D$ (southern quarter corner, 0.5 mile east of C).

Additional file 2. Metadata and spreadsheet of the data used to map the historical (1870s to 1880s) vegetation (prairie, savanna, forest) in the Palouse prairie-forest ecotone. We interpreted the field notes from General Land Office (GLO) surveys of the external lines of each township, and the internal lines subdividing each township into 36 sections for Washington, USA (www.blm.gov/or/landrecords/survey/yGrid_ORWA. php?state $=W A \& \mid n=10000000$, accessed April to November 2018), and Idaho, USA (glorecords.blm.gov/default.aspx, accessed April to November 2018). We used the species and number of bearing trees (0 to 4 ) at each of the section and quarter section corners to calculate the percent pine. The surveys were mostly completed between 1869 and 1916 (98\% of the 2793 GLO section corners in the ecotone with accessible records were surveyed between 1869 and 1883), and we excluded the Coeur d'Alene Indian Reservation lands as they were not surveyed until many years later. GLO surveyors recorded species and stem diameter at breast height $(1.3 \mathrm{~m})$ plus direction and distance from the section corner for up to four bearing trees within $60.2 \mathrm{~m}$ of each section corner with one in each quadrant (up to two trees for each quarter section corner, one in each half). Where there were no trees in a quadrant (section corners) or half (quarter section corners), they dug a pit instead from which they recorded direction and distance to the corner. Methods for GLO surveys are described by Bourdo (1956).

Additional file 3. We grouped individual Existing Vegetation Types (EVT) classes from LANDFIRE (www.landfire.gov) into nine broader groups: Agriculture, Conservation Reserve Program, Forest, Shrubland, Developed, Prairie, Riparian, Other grassland, and Water.

Additional file 4. Fire charts for sites included in this study (Table 1). Some sites were sampled for other studies (Table 1). Each horizontal line indicates the length of record for a single tree. The short vertical lines indicate years when that tree had evidence of fire (i.e., a fire scar). Recorder years (solid lines) generally follow the first scar on each tree. Non-recorder years (dashed lines) precede the formation of the first scar on each tree, but also occur when a period of the fire record was consumed by subsequent fires or decay. Inner and outer dates are the dates of the earliest or latest rings sampled for trees for which pith or bark was not sampled.

\section{Acknowledgements}

We dedicate this paper to L. Neuenschwander for all we've learned from him and with him about fire in the Palouse region. We especially thank $\mathrm{H}$.
Osborne, local forester, influential teacher of many, and former manager of the University of Idaho Experimental Forest. He located many fire-scarred stumps and helped to collect samples from them. We appreciate permission for sampling from private landowners (J. Carpenter, A. Stevens, G. and C. Weitz, H. Osborne family, and Bennett Lumber), the University of Idaho Experimental Forest, the Idaho State Parks and Recreation Department, and the managers of McCroskey State Park. K. Yedinak and M. Foard assisted with collecting samples from fire-scarred trees. EKH thanks the University of Washington's Helen Riaboff Whiteley Center, where parts of this manuscript were drafted.

\section{Authors' contributions}

PM, EKH, JPRII, EKS, and SCB conceived of the study. PM, EKS, and SCB conducted the GLO interpretation and analysis, building upon the approaches MJ used in her Master's thesis. EKH, JPRII, PM, and MNP collected the fire history data, and EKH analyzed them. JTA analyzed the modern fire and lightning records. SCB obtained the historical and current photo pairs: PM, EKH, EKS, and SCB drafted and revised the manuscript and then all authors helped in revising it. All of the authors reviewed and approved the final manuscript.

\section{Funding}

Funding was provided by USDA Forest Service Rocky Mountain Research Station through Agreements 12-JV-11221637-136 and 17-JV-11221637-132 with the University of Idaho. Funders were not involved in the details of study design, nor in data collection, analysis, or interpretation. Co-author EKH is a researcher with the USDA Forest Service Rocky Mountain Research Station.

\section{Availability of data and materials}

Our fire history data and samples, along with other details on the fire history sampling sites are available in International Multiproxy Paleofire Database (www.ncdc.noaa.gov/paleo/impd/paleofire.html). The other data supporting the conclusions of this article are included within the article and its additional files.

\section{Ethics approval and consent to participate}

Not applicable.

\section{Consent for publication}

All photographs are by the authors who grant permission for their use, or they were obtained with permission from Latah County and Idaho historical societies.

\section{Competing interests}

The authors declare that they have no competing interests.

\section{Author details}

${ }^{1}$ Department of Forest, Rangeland, and Fire Sciences, University of Idaho, 875 Perimeter Drive, Moscow, Idaho 83844, USA. ²USDA Forest Service, Rocky Mountain Research Station, Missoula Fire Sciences Laboratory, 5775 US Highway 10 West, Missoula, Montana 59808, USA. ${ }^{3}$ Department of Geography, University of Idaho, 875 Perimeter Drive, Moscow, Idaho 83844 USA. ${ }^{4}$ Department of Environmental Science and Management, Portland State University, P.O. Box 751, Portland, Oregon 97207, USA.

Received: 16 July 2019 Accepted: 31 October 2019

Published online: 16 January 2020

\section{References}

Abatzoglou, J.T., C.A. Kolden, J.K. Balch, and B.A. Bradley. 2016. Controls on interannual variability in lightning-caused fire activity in the western US. Environmental Research Letters 11 (4): 045005. https://doi.org/10.1088/17489326/11/4/045005.

Arno, S.F., and G.E. Gruell. 1983. Fire history at the forest-grassland ecotone in southwestern Montana. Journal of Range Management 36: 332-336. https:// doi.org/10.2307/3898481

Arno, S.F., and K.M. Sneck. 1977. A method for determining fire history in coniferous forests in the Mountain West. US Forest Service General Technical Report INT-GTR-42. Ogden: USDA Forest Service, Intermountain Forest and Range Experiment Station. 
Bailey, R.G. 1995. Description of the bioregions of the United States. Miscellaneous Publication 1391. Washington, D.C.: US Department of Agriculture, Forest Service.

Barbero, R., J.T. Abatzoglou, N.K. Larkin, C.A. Kolden, and B. Stocks. 2015. Climate change presents increased potential for very large fires in the contiguous United States. International Journal of Wildland Fire 24 (7): 892-899. https:// doi.org/10.1071/WF15083.

Barker, R.J. 1981. Soil survey of Latah County area, Idaho. Washington, D.C.: US Department of Agriculture, Soil Conservation Service.

Barrett, S.W., and S.F. Arno. 1982. Indian fires as an ecological influence in the northern Rockies. Journal of Forestry 80 (10): 647-651.

Bartlein, P.J., S.W. Hostetler, S.L. Shafer, J.O. Holman, and A.M. Solomon. 2008. Temporal and spatial structure in a daily wildfire-start data set from the western United States (1986-96). International Journal of Wildland Fire 17 (1): 8-17. https://doi.org/10.1071/WF07022.

Black, A.E., E. Strand, R.G. Wright, J.M. Scott, P. Morgan, and C. Watson. 1998. Land use history at multiple scales: implications for conservation planning. Landscape and Urban Planning 43 (1-3): 49-63. https://doi.org/10.1016/ S0169-2046(98)00096-6.

Bond, W.J., and J.E. Keeley. 2005. Fire as a global 'herbivore': the ecology and evolution of flammable ecosystems. Trends in Ecology \& Evolution 20 (7): 387394. https://doi.org/10.1016/j.tree.2005.04.025

Bourdo, E.A. 1956. A review of the General Land Office survey and of its use in quantitative studies of former forests. Ecology 37 (4): 754-768. https://doi.org/ 10.2307/1933067.

Bowman, D.M., J.K. Balch, P. Artaxo, W.J. Bond, J.M. Carlson, M.A. Cochrane, C.M. D'Antonio, R.S. DeFries, J.C. Doyle, S.P. Harrison, and F.H. Johnston. 2009. Fire in the Earth system. Science 324 (5926): 481-484. https://doi.org/10.1126/ science.1163886.

Bowman, D.M., J. Balch, P. Artaxo, W.J. Bond, M.A. Cochrane, C.M. D'Antonio, R. DeFries, F.H. Johnston, J.E. Keeley, M.A. Krawchuk, and C.A. Kull. 2011. The human dimension of fire regimes on Earth. Journal of Biogeography 38 (12): 2223-2236. https://doi.org/10.1111/j.1365-2699.2011.02595.x.

Bretz, J.H., H.T.U. Smith, and G.E. Neff. 1956. Channeled scabland of Washington: new data and interpretations. Geological Society of America Bulletin 67 (8): 957-1049. https://doi.org/10.1130/0016-7606(1956)67[957:CSOWND]2.0.CO;2.

Brown, P.M., and C.H. Sieg. 1999. Historical variability in fire at the ponderosa pineNorthern Great Plains prairie ecotone, southeastern Black Hills, South Dakota. Ecoscience 6 (4): 539-547. https://doi.org/10.1080/11956860.1999.11682563.

Conver, J.L., D.A. Falk, S.R. Yool, and R.R. Parmenter. 2018. Modeling fire pathways in montane grassland-forest ecotones. Fire Ecology 14 (1): 17-32. https://doi. org/10.4996/fireecology.140117031.

Cook, P.S., D.R. Becker, and M. Benedum. 2018. Idaho's family forest owners: 2016 survey results. Report 38. Moscow: University of Idaho Policy Analysis Group https://www.uidaho.edu/-/media/Uldaho-Responsive/Files/cnr/PAG/Research/ PAGreport38.pdf.

Cummins, K.L., M.J. Murphy, E.A. Bardo, W.L. Hiscox, R.B. Pyle, and A.E. Pifer. 1998 A combined TOA/MDF technology upgrade of the US National Lightning Detection Network. Journal of Geophysical Research 103 (D8): 9035-9044. https://doi.org/10.1029/98JD00153.

Daubenmire, R.F. 1942. An ecological study of the vegetation of southeastern Washington and adjacent Idaho. Ecological Monographs 12 (1): 53-79. https://doi.org/10.2307/1948422.

Daubenmire, R.F. 1970. Steppe vegetation of Washington. Technical Bulletin 62. Pullman: Washington Agricultural Experiment Station, Washington State University.

Donaldson, N.C. 1980. Soil survey of Whitman County, Washington. Washington, D.C.: US Department of Agriculture, Soil Conservation Service.

Donovan, S.M., C. Looney, T. Hanson, Y. Sánchez de León, J. Wulfhorst, S.D. Eigenbrode, M. Jennings, J. Johnson-Maynard, and N.A. Bosque Pérez. 2009. Reconciling social and biological needs in an endangered ecosystem: the Palouse as a model for bioregional planning. Ecology and Society 14 (1): 9. https://doi.org/10.5751/ES-02736-140109.

Duffin, A.P. 2007. Plowed under: agriculture and environment in the Palouse. Seattle: University of Washington Press.

Fischer, A.P., T.A. Spies, T.A. Steelman, C. Moseley, B.R. Johnson, J.D. Bailey, A.A. Ager, P. Bourgeron, S. Charnley, B.M. Collins, and J.D. Kline. 2016. Wildfire risk as a socioecological pathology. Frontiers in Ecology and the Environment 14 (5): 276284. https://doi.org/10.1002/fee.1283.

Goldberg, C.S., A. Pocewicz, M. Nielsen-Pincus, L.P. Waits, P. Morgan, J.E. Force, and L.A. Vierling. 2011. Predictions of ecological and social impacts of alternative residential development policies to inform decision making in a rural landscape. Conservation Letters 4 (6): 423-432. https://doi.org/10.1111/j. 1755-263X.2011.00194.X.

Grissino-Mayer, H.D. 2001. Evaluating crossdating accuracy: a manual and tutorial for the computer program COFECHA. Tree-Ring Research 57: 205-221.

Harvey, J.E., D. Smith, and T.T. Veblen. 2017. Mixed-severity fire history at a forestgrassland ecotone in west central British Columbia, Canada. Ecological Applications 127 (6): 1746-1760. https://doi.org/10.1002/eap.1563.

Hessburg, P.F., A.J. Larson, D.J. Churchill, R.D. Haugo, C. Miller, T.A. Spies, M.P. North, N.A. Povak, R.T. Belote, P.A. Singleton, W.L. Gaines, R.E. Keane, G.H. Aplet, S.L. Stephens, P. Morgan, P.A. Bisson, B.E. Rieman, R.B. Salter, and G.H. Reeves. 2015. Restoring fire-prone forest landscapes: seven core principles. Landscape Ecology 30 (10): 1805-1835. https://doi.org/10.1007/ s10980-015-0218-0.

Heyerdahl, E.K., L.B. Brubaker, and J.K. Agee. 2001. Spatial controls of historical fire regimes: a multiscale example from the Interior West, USA. Ecology 82 (3): 660-678. https://doi.org/10.1890/0012-9658(2001)082[0660:SCOHFR]2.0.CO;2.

Heyerdahl, E.K., P. Morgan, and J.P. Riser II. 2008a. Crossdated fire histories (1650 to 1900) from ponderosa pine-dominated forests of Idaho and western Montana. US Forest Service General Technical Report RMRS-GTR-214. Fort Collins: USDA Forest Service, Rocky Mountain Research Station. https://doi. org/10.2737/RMRS-GTR-214.

Heyerdahl, E.K., P. Morgan, and J.P. Riser. 2008b. Multi-season climate synchronized historical fires in dry forests (1650-1900), northern Rockies, USA. Ecology 89 (3): 705-716. https://doi.org/10.1890/06-2047.1.

Hironaka, M., M.A. Fosberg, and K.E. Neiman Jr. 1991. The relationship between soils and vegetation. In Proceedings - management and productivity of western-montane forest soils. US Forest Service General Technical Report INT280. Compiled by A. Harvey and L.F. Neuenschwander. Pages 29-31. Fort Collins: USDA Forest Service, Intermountain Research Station. https://doi.org/ 10.2737/INT-GTR-280.

IDFG [Idaho Fish and Game]. 2015. Idaho State Wildlife Action Plan. Boise: Idaho Fish and Game https://idfg.idaho.gov/swap. Accessed 25 Nov 2018.

Johnson, M.P. 1999. Estimating the pre-European settlement occurrence of ponderosa pine in Latah County, Idaho. Thesis, University of Idaho, Moscow, USA.

Kitzberger, T. 2012. Ecotones as complex arenas of disturbance, climate, and human impacts: the trans-Andean forest-steppe ecotone of northern Patagonia. In Ecotones between forest and grassland, ed. R.W. Myster, 59-88. New York: Springer. https://doi.org/10.1007/978-1-4614-3797-0_3.

Ladwig, L.M., E.I. Damschen, and D.A. Rogers. 2018. Six years of community change in the prairie-savanna-forest mosaic of Wisconsin. Ecology and Evolution 8: 8458-8466. https://doi.org/10.1002/ece3.4251.

Looney, C., and S.D. Eigenbrode. 2012. Characteristics and distribution of Palouse Prairie remnants: implications for conservation planning. Natural Areas Journal 32 (1): 75-85. https://doi.org/10.3375/043.032.0109.

Meinig, D.W. 1968. The great Columbia Plain: a historical geography, 1805-1910. Seattle: University of Washington Press.

Merschel, A.G., E.K. Heyerdahl, T.A. Spies, and R.A. Loehman. 2018. Influence of landscape structure, topography, and forest type on spatial variation in historical fire regimes, central Oregon, USA. Landscape Ecology 33 (7): 11951209. https://doi.org/10.1007/s10980-018-0656-6.

Morgan, P., E.K. Heyerdahl, and C.E. Gibson. 2008. Multi-season climate synchronized widespread forest fires throughout the 20th century, Northern Rockies, USA. Ecology 89 (3): 717-728. https://doi.org/10.1890/06-2049.1.

Morgan, P., E.K. Heyerdahl, C. Miller, and A.M. Wilson. 2014. Northern Rockies pyrogeography: an example of fire atlas utility. Fire Ecology 10 (1): 14-30. https://doi.org/10.4996/fireecology.1001014.

Neiman, K.E., Jr. 1988. Soil characteristics as an aid to identifying forest habitat types in northern Idaho. US Forest Service Research Paper INT-RP-390. Ogden: USDA Forest Service, Intermountain Research Station.

Nielsen-Pincus, M., C.S. Goldberg, A. Pocewicz, J.E. Force, L.P. Waits, P. Morgan, and L. Vierling. 2010. Predicted effects of residential development on a northern Idaho landscape under alternative growth management and land protection policies. Landscape and Urban Planning 94 (3-4): 255-263. https:// doi.org/10.1016/j.landurbplan.2009.10.011.

Noss, R.F., E.T. LaRoe, and J.M. Scott. 1995. Endangered ecosystems of the United States: a preliminary assessment of loss and degradation. Biological Report 28. Washington, D.C.: US Department of the Interior, National Biological Service https://iucnrle.org/static/media/uploads/references/background/ assessments/noss-etal-1995-endangered-ecosystems-usa-preliminaryassessment-loss-degradation-en.pdf Accessed 22 Apr 2018. 
Paveglio, T.B., H. Brenkert-Smith, T. Hall, and A.M. Smith. 2015. Understanding social impact from wildfires: advancing means for assessment. International Journal of Wildland Fire 24 (2): 212-224. https://doi.org/10.1071/WF14091.

Peterson, L. 2004. Climatic drivers of wildfire regimes in northern Idaho. In Senior thesis. Colorado Springs: The Colorado College.

Pocewicz, A., M. Nielsen-Pincus, C.S. Goldberg, M.H. Johnson, P. Morgan, J.E. Force, L.P. Waits, and L. Vierling. 2008. Predicting land use change: comparison of models based on landowner surveys and historical land cover trends. Landscape Ecology 23 (2): 195-210. https://doi.org/10.1007/s10980-007-9159-6.

Roberts, M.J., and R.N. Lubowski. 2007. Enduring impacts of land retirement policies: evidence from the Conservation Reserve Program. Land Economics 83 (4): 516-538. https://doi.org/10.3368/le.83.4.516.

Samson, F., and F. Knopf. 1994. Prairie conservation in North America. BioScience 44 (6): 418-421. https://doi.org/10.2307/1312365.

Short, K.C. 2017. Spatial wildfire occurrence data for the United States, 1992-2015 [FPA_FOD_20170508]. 4th edition Fort Collins: USDA Forest Service Research Data Archive. https://doi.org/10.2737/RDS-2013-0009.4.

Syphard, A.D., V.C. Radeloff, J.E. Keeley, T.J. Hawbaker, M.K. Clayton, S.I. Stewart, and R.B. Hammer. 2007. Human influence on California fire regimes. Ecological Applications 17 (5): 1388-1402. https://doi.org/10.1890/06-1128.1.

Tisdale, E.W. 1961. Ecologic changes in the Palouse. Northwest Science 35 (4): 134-138.

Weaver, J.E. 1917. A study of the vegetation of southeastern Washington and adjacent Idaho. University of Nebraska Studies 17 (1): 1-133. https://doi.org/10. 5962/bhl.title.23662.

Westerling, A.L. 2016. Increasing western US forest wildfire activity: sensitivity to changes in the timing of spring. Philosophical Transactions of the Royal Society B 371 (1696): 20150178. https://doi.org/10.1098/rstb.2015.0178.

Whitlock, C., J. Marlon, C. Briles, A. Brunelle, C. Long, and P. Bartlein. 2008. Longterm relations among fire, fuel, and climate in the northwestern US based on lake-sediment studies. International Journal of Wildland Fire 17 (1): 72-83. https://doi.org/10.1071/WF07025.

\section{Publisher's Note}

Springer Nature remains neutral with regard to jurisdictional claims in published maps and institutional affiliations.

\section{Submit your manuscript to a SpringerOpen ${ }^{\circ}$ journal and benefit from:}

- Convenient online submission

- Rigorous peer review

- Open access: articles freely available online

High visibility within the field

- Retaining the copyright to your article

Submit your next manuscript at $\boldsymbol{\nabla}$ springeropen.com 